\title{
Intervention Selection to the Awareness of Energy-Saving Behavior in the Public Sector
}

\author{
Rozza Linda ${ }^{1, *}$ Lusi Susanti ${ }^{2}$, and Hilma Raimona Zadry ${ }^{2}$ \\ ${ }^{1}$ Industrial Engineering Department, Faculty of Engineering, Ekasakti University, Padang, Indonesia \\ ${ }^{2}$ Departement of Industrial Engineering, Faculty of Engineering, Andalas University, Limau Manis, \\ Padang, West Sumatera, Indonesia
}

\begin{abstract}
Nowadays Indonesia is facing energy scarcity and still struggling with finding new energy resources. No other ways the employee have to use the currently available energy wisely. However wasteful behavior in energy use is still often seen in public sectors like government/private buildings, schools/campuses, hospital, and others. Various effort (such as energy saving campaign through mass media, pamphlet, etc) have been made by the building managers or owners to encourage users energy-saving behavior through various channels but found ineffective. Therefore, this study was conducted to select the alternative intervention to increase the awareness of energy-saving behavior in Indonesia by referring to the conceptual model of ABC (Antecedents-Behavior-Consequences) behavioral pattern. Several samples were taken from several public buildings, including government/private institutions, schools/campuses, hospital and mosques in Padang city. Data were collected through questionnaires filled by 30 respondents in each sector. The result shows that the phase of antecedent, the most appropriate type of intervention to build awareness of energy saving behavior for people is by making strong commitments in each building sector and the local government. In the consequence phase there are two criteria selected: reward and finance/legislation. The reward can be delivered for example, through providing a discount voucher or tax reduction. As for the consequence on finance/legislation can be done by creating and controlling the implementation of government regulations that are related to the electricity saving problem in public sector.
\end{abstract}

\section{Introduction}

Electricity still dominates the final energy consumption in Indonesia. The level of electricity demand is estimated to grow about $8.5 \%$ per year with the assumption of population grow of $1.1 \%$ per year [6]. If the trend of electricity consumption still follows business as usual (BAU) like today, Indonesia will experience electricity shortages shortly. This is exacerbated by the fact that Indonesia falls into the category of a country is wasted in electricity consumption in ASEAN. The problem of wasting electricity energy is generally caused by human factor ( $80 \%)$ and by technical factor $20 \%$ [5]. This wasteful behavior is increasingly being seen in public facility buildings, such as government/ private buildings,

\footnotetext{
*Corresponding author: lusi@eng.unand.ac.id
} 
schools/campuses, hospital and others. One study conducted by Yang et al [8] The energy consumtion was calculated for each activity category (lighting, cooling, cooking, entertinment and other device) [7] states that energy consumption per square meter in office buildings spend about $70-300 \mathrm{KWH}$ or equal $10-20$ times greater than that consumption by households.

The public sector is still one source of energy waste in Indonesia. Efforts have been made by the goverment to encourage people's energy saving behavior through various channels such as public service announcements, posters, oral and written appeals, but the impact of the appeal is very small. Thus, it is needed an internal stimulus in arising the awareness/action which more concerned with the environment. Yik and Lee [9] stated that a lack of awareness of the importance of energy saving behavior is a major cause of energy wastage.

The Three Term Contingency theory is also known as the A-B-C model (Antecedences Behavior - Consequences) [4]. This model explains how energy wastage occurs: Antecedences are the circumstances or situation that exist in the environment before a behavior is taken. Behavior shows how a person thinks, act and makes the decision that produce impact or consequences on the next process. While consequences is a situation that is instantaneous or in the long run is expected in accordance with the expected target behavior. If this behavior is reinforced, repeated that it becomes a habit, then the target to generate awareness of energy saving behavior can be expected.

So in encouraging energy-saving behavior in the public sector, it is necessary to conduct empirical studies of the types of interventions that are most appropriate to be applied based on the concept of Three-Term Contingency model, to produce the expected target behavior. This study aims to determine the most appropriate intervention for Indonesian society in building awareness of energy efficient behavior in the public sector.

\section{Method}

Respondent of the study are people related to the policy in the use of electrical energy as well as who understand about the conservation of electric energy in government/private institution, schools/colleges, hospitals and mosques.

\subsection{Data collection and Analysis}

Data collection was done by distributing questionnaires to predetermined public sector electricity users. The questionnaires were distributed as many as 120 pieces with 30 items for each sector (government/private, schools/colleges, hospitals and mosques) groups. Data processing is done on the questionnaires that have been collected. Data processing is done by AHP method using Expert Choice software version 2000.

The analysis was conducted on the result of data processing with AHP in the form of the most appropriate types of interventions to be conducted in the public sector in Indonesia to carry out energy-saving effort.

\section{Result and Discussion}

\subsection{Questionnaire Distributions}

Questionnaires were distributed to 120 respondents from government/private institutions, schools/colleges, hospitals, and mosques. The questionnaires were distributed for five months, from March 2017 to July 2017. 


\subsection{Pair Comparison}

Pair comparisons are based on expert judgment which compares an element to other elements. Pair comparison of data using expert choice software. Priority is determined from the highest weight criteria. The elements selected in the priories are used as the most appropriate solution to the problem. The result found that the top three criteria selected in each agency is the commitment goal, reward and finance/legislation. Table 1 shows the alternative selected on the three criteria in each agency.

Table 1. Selected alternative for intervention of awareness to energy saving behavior

\begin{tabular}{|c|c|c|c|}
\hline Sector & Selected Criteria & Selected Alternative & Assessment (\%) \\
\hline \multirow{8}{*}{$\begin{array}{c}\text { Government / private } \\
\text { agency }\end{array}$} & \multirow{3}{*}{ Commitment goal } & With municipality & 43.9 \\
\hline & & With employee & 41.4 \\
\hline & & With same institute & 14.7 \\
\hline & \multirow{2}{*}{ Reward } & Awards/prizes & 85.9 \\
\hline & & Tax deduction from land value tax & 14.1 \\
\hline & \multirow{3}{*}{ Finance /Legislation } & \begin{tabular}{|l|} 
Legislation \\
\end{tabular} & 55.4 \\
\hline & & Price policies & 28.9 \\
\hline & & Subsidies & 15.7 \\
\hline \multirow{8}{*}{ Schools/colleges } & \multirow{3}{*}{ Commitment goal } & With municipality & 43.0 \\
\hline & & With employee & 40.2 \\
\hline & & With same institute & 16.8 \\
\hline & \multirow{2}{*}{ Reward } & Awards/prizes & 85.8 \\
\hline & & Tax deduction from land value tax & 14.2 \\
\hline & \multirow{3}{*}{ Finance /Legislation } & Legislation & 56.6 \\
\hline & & Price policies & 27.1 \\
\hline & & \begin{tabular}{|l|} 
Subsidies \\
\end{tabular} & 16.3 \\
\hline \multirow{8}{*}{ Hospitals } & \multirow{3}{*}{ Commitment goal } & With municipality & 42.8 \\
\hline & & With employee & 43.3 \\
\hline & & With same institute & 13.9 \\
\hline & \multirow{2}{*}{ Reward } & Awards/prizes & 86.1 \\
\hline & & Tax deduction from land value tax & 13.9 \\
\hline & \multirow{3}{*}{ Finance /Legislation } & \begin{tabular}{|l|} 
Legislation \\
\end{tabular} & 56.8 \\
\hline & & Price policies & 27.4 \\
\hline & & Subsidies & 15.8 \\
\hline \multirow{8}{*}{ Mosques } & \multirow{3}{*}{ Commitment goal } & With municipality & 41.3 \\
\hline & & With employee & 45.2 \\
\hline & & With same institute & 13.5 \\
\hline & \multirow{2}{*}{ Reward } & Awards/prizes & 85.3 \\
\hline & & Tax deduction from land value tax & 14.7 \\
\hline & \multirow{3}{*}{ Finance /Legislation } & Legislation & 57.2 \\
\hline & & Price policies & 26.8 \\
\hline & & Subsidies & 16.0 \\
\hline
\end{tabular}

\subsection{Analysis}

\subsubsection{Intervention on the Antecedent Phase}

Goal commitment intervention is the selected intervention for antecedent phase. This intervention does not require high technology and great cost in the implementation and easy to follow up. Continuous commitment by an agency will change employee behavior if this is accompanied by continuous control by the authorities in an agency. To change the behavior of an individual/ employee in the public sector, it requires leadership with character and strict control system so that, the energy saving commitment can be implemented properly.

Selected alternative to goal commitment in government/private institutions, schools/colleges and hospitals are commitment by municipalities/government. This indicates that in the three institutions, the role of funders or owners of foundation in private institutions 
is very effective commit to realize energy saving behavior. As for the selected alternative mosque is a commitment to employees or in this case the offices/administrators of the mosque. It caused by the mosque funding are came from self-help community, so that the role of the employee is very dominant.

The form of commitment to government/private institution can be implemented by:

1. Forming a task force tasked with controlling energy use in the building.

2. Making the warning about the call to behave energy efficient

3. Creating written guidance on how to perform energy saving measure that is circulated to all sub-sections and also posted on strategic places in the office.

4. Conducting appeal and direction to all employees in every morning apple execution.

Commitment to schools/colleges can be realized in following ways:

1. Making the written guidance on how to conduct energy saving measure that is circulated the entire academic community and also tacked on strategic places in the schools/colleges.

2. Giving appeal to all students in the class to always behave energy efficient.

3. Improving the function of security officers to always control the use of energy in schools/colleges.

4. Providing the warning about the call to behave energy efficient.

Commitment to the hospitals can be done in the following ways:

1. Making written guidance on how to perform energy saving measures tailored to the sub-section of the hospital's work, because in the hospital, it has specialized tools whose use in understood only by certain people.

2. Creating written guidance on how to perform energy saving measures posted on the hospital's outpatient and strategic premises.

3. Providing the warning about the call to behave energy efficient.

Implementation of commitment to the mosque can be done in more simple way than three agencies above, because the energy user in the mosque is a congregation who come worship. Implementation of commitment to the mosque can be done by mosque officers who at the same time control the use of energy in the mosque.

\subsubsection{Intervention in Consequence Phase}

The selected consequence found are two intervention, namely reward interventions and finance/legislation intervention.

\section{a) Intervention in the Form of Reward}

Giving the reward to agencies that succeeded in making energy efficient effort in one of the most effective ways to be done in the public sector in Indonesia. This can provide motivation and stimulation of a person is behaving.

Asriani et al. [1] study indicated a significant influence between the provisions of reward to the employee to work discipline. However, this reward is only a short term effect [2]. Choosing the right form of reward is very important, but rewarding is a huge cost. Giving reward to the public sector in Indonesia can be realized for example in the form of discount voucher charging fuel to all employee who successfully makes energy-saving effort.

\section{b) Intervention in the form of Legislation}

The legislation is selected because government regulation is a force in a country to implement a commitment, so it is expected to effect on behavior change in the public sector. However, this method should be accompanied by clear sanction for agencies that do not implement these government regulation to make this regulation effective. The energy saving of the public sector in Indonesia is regulated by Minister of Energy and Mineral Resources No. 14 of 2012. In article 12 it is explained that the electrical energy saving in public sector can be done through: air system, light system, supporting-equipment, production process, and main 
energy utilization equipment. However, in the implement of the Minister's regulation to be effective, there should be sanction for agencies that do not implementation the regulation.

The sanctions that can be applied to government/private sector in the form of warning letters, enforce the high tax, reduce aid and revocation of operational permits. The sanction can also be applied to schools/colleges and hospitals. As for the mosques can by appealing to mosque officials to conduct energy saving measure or give a letter of reprimand to the mosque management who do not perform energy-saving measure.

\section{Conclusion}

This study found the most appropriate type of intervention to build the awareness of energy saving behavior in the public sector in Indonesia in the antecedent phase and the consequence phase. In the antecedent phase, it is suggested to make the strong commitment in every institution and local government to implement electrical energy saving measures. A form of commitment that can be done by each agency is to provide direction and appeal by the government and their respective leaders if all employees to perform energy-saving measures.

In the consequence phase, there are two criteria selected: reward and finance/legislation. One form of reward is given in the form of discount voucher fuel replenishment. As for the consequences on finance/legislation can be done by creating and controlling government regulations relating to electricity saving public sector in Indonesia.

Future research is advised to examine the effect of selected interventions on energy saving behavior in the public sector in Indonesia. This will provide more accurate information on alternative interventions in build awareness of electrical energy-saving behavior in the public sector in Indonesia.

The acknowledgement this study is partly funded by Ristek-Dikti through PDUPT Grant No. 018/UN.16.17/PP.PDUPT.EET/LPPM/2018.

\section{Reference}

1. Asriani, D. Gimin, Nas, S. Efect of Reward on PT.Citra Riau Sarana's employee work in Kuantan Singingi Regency. University of Riau (2014).

2. Geller, E. The Challenge of Increasing Proenvironmental Behavior, In:Bechtel, R., Churchman, A (Eds.), Handbook of Environmental Psychology (Wiley, New York, 2002)

3. Lestari, E. Analysis of Decision Support Systems for the Process of Increasing Position on PT X. 1/3/J-SI/2009, (2009)

4. Maag, J.W, Behavior Management : From Theoretical Implication to Practical Application Belmont, CA : Thomson/Wadsworth, (2004)

5. ESDM Regulation No. 13 of 2012, Guidelines for Energy Savings in Government Buildings. Jakarta (2012).

6. PT. PLN (Pesero), PLN Statistics. PT PLN Jakarta Secretariat (2015)

7. Sukarno I, Susanti L, Household Lifestyle Effect on Residential Electrical Energy Consumtion in Indonesia. (2017).

8. Yang, L., Joseph, C., Lam, Tsang, C.L., Energy Performance of Building Envelopes in Different Climate Zones in China. Applied Energy 9, 800-817 (2008)

9. Yik, F.W.H. and Lee, W.L., A Preliminary Inquiry into Why Buildings Remain Energy Inefficiency and Potential Remedy. Transaction, The Hongkong Institute of Engineers 1, 2-3 (2002) 